\title{
Correlation of Calcium, Phosphorus, Uric Acid and Magnesium Level in Serum and 24 hours Urine of Patients with Urolithiasis
}

\author{
Gyawali PR, Joshi BR, Gurung CK
}

Department of Urology

Tribhuwan University Teaching Hospital

Maharajgunj, Kathmandu.

Corresponding Author

Dr. Prem Raj Gyawali

Department of Urology

Tribhuwan University Teaching Hospital

Maharajgunj, Kathmandu.

email: premgyawali33@yahoo.com

Citation

Gyawali PR. Correlation of calcium, phosphorus, uric acid and magnesium Level in serum and 24 hours urine of patients with urolithiasis. Kathmandu Univ Med J 2011;34(2)54-6.

\begin{abstract}
Background

ABSTRACT

Bakcground

Urinary stones disease is common pathology encountered in urological practice in Nepal. Supersaturated urine and its stagnation are well known facts for the development of urolithiasis. Metabolic disorders like hypercalciuria, hyperuricaemia, hypocitraturia are also responsible for formation of urolithiasis.
\end{abstract}

\section{Objective}

The aim of this study was to identify the level of calcium, phosphorus, uric acid, and magnesium in the blood and urine of Nepalese patients with urinary stones.

\section{Methods}

This study was conducted over a period of six months (From May to November 2010). It is a descriptive cross sectional study and quantitative method was used for analysis. Primary data were collected and utilized from 79 cases.

\section{Results:}

The prevalence of urolithiasis in male patients was $65.8 \%$ and $34.2 \%$ in female patients $(p<0.05)$. Serum calcium in stone former and non-stone former was $8.3 \pm 1.2$ and $7.5 \pm 1.5(p<0.01)$ respectively. Serum phosphorus and uric acid in both groups were statistically not significant ( $p$ value 0.269 and 0.597 respectively) though in 24 hours urine of stone formers value of phosphorus was $447.9 \pm 182.4$ but in non-stone formers it was $186.5 \pm 118.7(p<0.001)$. Magnesium level in urine was $48.1 \pm 69.7$ and $131.4 \pm 86.9(p<0.001)$ respectively.

\section{Conclusion}

Higher level of calcium in serum was found in patients with urolithiasis in our population. Though phosphate level in blood serum was not different in the both groups but in urine phosphate and magnesium levels were significantly different.

\section{KEY WORDS}

hypercalciuria, hyperphosphaturia, hyperuricosuria, hypocitraturia, urolithiasis

\section{INTRODUCTION}

Urolithiasis is a common clinical disorder affecting large amount of population worldwide. About $10 \%$ of people will experience nephrolithiasis in their lifetime and about $50-70 \%$ of those will have recurrences. ${ }^{1,2}$ The prevalence of renal stone disease has been rising in both sexes and in certain areas of the world like south Asia; the lifetime risk appears to be even higher. A lot of resources are been used in the treatment of urinary stones worldwide but its prevention is been neglected field. So the aim of this study was to identify the level of calcium, phosphorus, uric acid and magnesium in the blood and urine of Nepalese patients with urinary stones.

\section{METHODS}

This is a prospective study, conducted in Tribhuwan University Teaching Hospital, Maharajgunj, Kathmandu Nepal over a period of six months (from May to November 2010). The study is descriptive and explorative cross sectional study where quantitative methods were used. Total 79 cases were collected during the study period and they were divided into two groups. Group I- Patients visiting to the hospital with urinary stones (Cases) - Stone formers and Group II- People of similar age and sex matched group without urinary stones (Controls) - Non stone formers. All patients with urinary stones were included in the study but those who needed immediate intervention to release 
obstruction due to urinary stones were excluded from the study. Five $\mathrm{ml}$ venous blood and 24 hours urine was collected from both groups. Validity and reliability of the study were ensured by standardization and calibration of laboratory methods. Surgery to remove stones was performed by consultant urologist (PRG).

The data were categorized according to presence or absence of urolithiasis. The patients with calculi were further subdivided based on the type of urolithiasis (Chemical composition-Calcium oxalate vs. others). Data analysis was done using Statistical Package for Social Sciences (SPSS) version17.0. $P$ value $<0.05$ was considered significant.

\section{RESULTS}

A total of 79 people (44 cases and 35 controls) were eligible for final data analysis. The mean age of the patients was $40.2 \pm 14.5$ years, out of which $52(65.8 \%)$ were male. Urinary stones was more prevalent (27\%) in 26-35 years of age. Ethnicity wise the most common group of patients were Brahmin (38\%), followed by Janjati (23\%) and others. A total of $59 \%$ patients had comorbid conditions such as diabetes mellitus, hypertension and others.

Table 1. Comparison of participants with and without urolithiasis.

\begin{tabular}{|c|c|c|c|c|}
\hline \multirow{2}{*}{\multicolumn{2}{|c|}{ Variable }} & \multicolumn{2}{|l|}{ Participants } & \multirow[t]{2}{*}{$\mathrm{p}$ value } \\
\hline & & $\begin{array}{l}\text { With stones } \\
(n=44)\end{array}$ & $\begin{array}{l}\text { Without } \\
\text { stones } \\
(n=35)\end{array}$ & \\
\hline \multicolumn{2}{|l|}{ Age (years) } & $40.0 \pm 14.1$ & $40.5 \pm 15.3$ & 0.877 \\
\hline \multirow[t]{2}{*}{ Sex } & Male & 30 & 23 & 0.81 \\
\hline & Female & 14 & 12 & \\
\hline \multicolumn{2}{|c|}{ Daily fluid intake ( L) } & $2.3 \pm 0.7$ & $2.2 \pm 0.7$ & 0.688 \\
\hline \multicolumn{2}{|l|}{$\mathrm{Hb}(\mathrm{g} / \mathrm{dl})$} & $13.4 \pm 1.6$ & $12.4 \pm 1.9$ & $0.016 * *$ \\
\hline \multicolumn{2}{|l|}{ PCV (\%) } & $41.5 \pm 4.8$ & $37.8 \pm 6.1$ & $0.004 * *$ \\
\hline \multicolumn{2}{|c|}{ Blood urea (mg/dl) } & $28.4 \pm 8.2$ & $36.8 \pm 13.6$ & $0.001 * *$ \\
\hline \multicolumn{2}{|c|}{ Serum creatinine (mg/dl) } & $0.9 \pm 0.2$ & $1.3 \pm 0.6$ & $0.001 * *$ \\
\hline \multicolumn{2}{|c|}{ Serum calcium (mg/dl) } & $8.3 \pm 1.2$ & $7.5 \pm 1.5$ & $0.012 * *$ \\
\hline \multicolumn{2}{|c|}{ Serum phosphorus } & $3.8 \pm 0.9$ & $3.7 \pm 0.5$ & 0.724 \\
\hline \multicolumn{2}{|c|}{ Serum uric acid(mg/dl) } & $5.2 \pm 1.2$ & $5.8 \pm 1.1$ & $0.039 * *$ \\
\hline \multicolumn{2}{|c|}{24 hour urine (ml) } & $3095 \pm 1124$ & $3057 \pm 1033$ & 0.877 \\
\hline \multicolumn{2}{|c|}{$\begin{array}{l}24 \text { hour urine calcium } \\
\text { (mg) }\end{array}$} & $161.4 \pm 82.3$ & $137.3 \pm 122.9$ & 0.301 \\
\hline \multicolumn{2}{|c|}{$\begin{array}{l}24 \text { hour urine phosphorus } \\
\text { (mg) }\end{array}$} & $447.9 \pm 182.4$ & $186.5 \pm 118.7$ & $0.0001^{* *}$ \\
\hline \multicolumn{2}{|c|}{$\begin{array}{l}24 \text { hour urine uric } \\
\operatorname{acid}(\mathrm{mg})\end{array}$} & $525.2 \pm 261.2$ & $472.6 \pm 333.5$ & 0.434 \\
\hline \multicolumn{2}{|c|}{$\begin{array}{l}24 \text { hour urine } \\
\text { magnesium(mg) }\end{array}$} & $48.1 \pm 69.7$ & $131.4 \pm 86.9$ & $.0001 * *$ \\
\hline \multicolumn{2}{|c|}{24 hour urine protein $(\mathrm{mg})$} & $258.7 \pm 197.2$ & $262.8 \pm 328.9$ & 0.946 \\
\hline
\end{tabular}

$* *$ p-Value $<0.05$ statistically significant (Independent Sample t- test)

Out of the 44 patients with urolithiasis, $77 \%$ of the patients had primary stone followed by recurrent (18\%) and residual stones (5\%). The most common site of urolithiasis was kidney (86.3\%). Twenty three per cent of the patients had history of previous surgery for urinary stones.

Table 2. Comparison of calcium oxalate and other type of urolithiasis.

\begin{tabular}{|c|c|c|c|}
\hline \multirow[t]{3}{*}{ Parameters } & \multicolumn{2}{|l|}{ Urolithiasis } & \multirow[t]{3}{*}{$p$ value } \\
\hline & $\begin{array}{l}\text { Calcium Oxalate } \\
(n=33)\end{array}$ & $\begin{array}{l}\text { Others } \\
(n=11)\end{array}$ & \\
\hline & (Mean $\pm S D)$ & (Mean $\pm S D)$ & \\
\hline Age (years) & $40.4 \pm 13.1$ & $38.5 \pm 17.4$ & 0.698 \\
\hline Daily fluid intake ( L) & $2.3 \pm 0.6$ & $2.3 \pm 0.8$ & 0.953 \\
\hline Blood urea (mg/dl) & $28.8 \pm 7.6$ & $27.1 \pm 10$ & 0.567 \\
\hline $\begin{array}{l}\text { Serum Creatinine (mg/ } \\
\text { dl) }\end{array}$ & $0.936 \pm 0.1$ & $1.0 \pm 0.2$ & 0.189 \\
\hline Serum calcium (mg/dl) & $8.4 \pm 1.1$ & $8.0 \pm 1.6$ & 0.383 \\
\hline Serum phosphorus & $3.9 \pm 1$ & $3.5 \pm 0.4$ & 0.269 \\
\hline Serum uric acid (mg/dl) & $5.3 \pm 1.4$ & $5.1 \pm 0.8$ & 0.597 \\
\hline 24 hour urine (ml) & $3006 \pm 998.4$ & $3363.6 \pm 1463.7$ & 0.367 \\
\hline $\begin{array}{l}24 \text { hour urine calcium } \\
\text { (mg) }\end{array}$ & $165.4 \pm 83.8$ & $149.4 \pm 80.3$ & 0.581 \\
\hline $\begin{array}{l}24 \text { hour urine phospho- } \\
\text { rus (mg) }\end{array}$ & $454.4 \pm 202.7$ & $428.2 \pm 104.6$ & 0.685 \\
\hline $\begin{array}{l}24 \text { hour urine uric acid } \\
\text { (mg) }\end{array}$ & $546.7 \pm 289.0$ & $460.9 \pm 141.6$ & 0.351 \\
\hline $\begin{array}{l}24 \text { hour urine magne- } \\
\text { sium (mg) }\end{array}$ & $41.7 \pm 66.7$ & $67.3 \pm 78.2$ & 0.298 \\
\hline $\begin{array}{l}24 \mathrm{hr} \text { urine protein } \\
\text { (mg) }\end{array}$ & $247.6 \pm 197.2$ & $291.9 \pm 202.7$ & 0.525 \\
\hline
\end{tabular}

${ }^{* *}$ p-Value $<0.05$ Statistically Significant (Independent Sample t- test)

On correlation analysis there is a strong positive correlation between the amount of daily fluid intake and $24 \mathrm{hr}$ urine output ( $r=0.417 ; p=0.005)$, weak negative correlation between $24 \mathrm{hr}$ urine calcium and magnesium( $r=-0.160$; $\mathrm{p}=0.299)$, weak negative correlation between $24 \mathrm{hr}$ urine calcium and $24 \mathrm{hr}$ urine protein ( $r=0.180 ; p=0.437)$, and weak positive correlation between serum calcium and 24 hr urine phosphorus $(r=0.180 ; p=0.243)$.

\section{DISCUSSION}

In the present study, different metabolites of 24-hour urine sample and serum parameters were assessed in patients with urolithiasis. We investigated the correlations between different parameters of 24-hour urine in patients with urolithiasis and found a different aspect of biochemical values in patients with urolithiasis. It is known that while the raised excretion of oxalate, uric acid, calcium and phosphorus in the urine increase the formation of urolithiasis; raised excretion of citrate, magnesium, albumin and alkali in urine decrease this process. In our patients with urolithiasis the levels of serum and urinary calcium, uric acid, phosphorus and magnesium and protein were within normal limits but the levels of serum calcium and uric acids were higher than in control group. Likewise, 24-hour urinary phosphate was higher and 24-hour urinary magnesium was lower in patients with urolithiasis in comparison to the controls. None of the patients 
in our study had hypercalcemia, hyperphosphatemia, hyperuricaemia, hypercalciuria, hyperphosphaturia and hyperuricosuria.

\section{Fluid intake, urine output and urolithiasis}

In our study there was a significant correlation between 24 hr fluid intake and urine output but there was no significant difference in patients with and without urolithiasis in terms of $24 \mathrm{hr}$ fluid intake and urolithiasis. The results of our study are akin to the findings of the study done by Jaywalker et al. In their study as well there was no significant difference in 24 hr urine output. ${ }^{3}$

Despite the evidence that the urine volume was the most important risk factor of all parameters evaluated, there are few studies carried out to support the assumption of prophylactic effects of an adequate fluid intake. Frank et al compared the incidence of urinary stone formation and found that the increase in urine volume was capable of preventing urinary stone formation in hot dry desert areas. A long-term prospective study in patients with idiopathic, recurrent urolithiasis demonstrated that patients with relapse during at least 2 years of follow-up had increased their urine volume to a lower extent. The sole prospective randomized study on the role of fluid intake as a preventive measure in urinary stone formation was performed by Borghi et al. ${ }^{4}$ They studied 101 controls and 199 patients from the first idiopathic stone episode. During the 5-year follow-up period, patients in the intervention group had significantly higher urine volumes (2.1-2.6 vs. 1.0-1.2 l/24 h), a $50 \%$ lower recurrence rate ( 27 vs. $12.1 \%$ ), and a longer time to first recurrence (38.7 vs. 25.1 months). The study confirms that urine volume is a real risk factor in urolithiasis and that an increase in fluid intake to at least $2 \mathrm{l} /$ day is the initial therapy for the prevention of stone recurrences.

\section{Serum biochemical parameters and urolithiasis}

We have studied various serum physiochemical risk factors for Urolithiasis. In our patients with urolithiasis, though the levels of serum calcium, uric acid, phosphorus and magnesium and protein were within normal limits, the levels of serum calcium and uric acids were higher than in patients without urolithiasis. Though hypercalcemia and hyperuricaemia are definite risk factors for urolithiasis, in our set up normocalcaemic and normouricaemic patients have urinary stones. This can be explained by multifactorial etiology of the urinary stone and some genetic variation in Nepalese patients. There are many studies showing hypercalcemia and hyperuricaemia as risk factors for urolithiasis. Study done by Jawalekar et al reveals that in patients with urolithiasis serum calcium level was significantly higher than that in controls calcium ( $\mathrm{mmol} / \mathrm{l}$ ) $4.9 \pm 0.21$ vs $2.4 \pm 0.12 p<.03] .{ }^{3}$ However there was no significant difference in serum uric acid level in that study.

\section{Urine biochemical risk factors and urolithiasis}

In our study the patients with urolithiasis had low $24 \mathrm{hr}$ urinary magnesium and high $24 \mathrm{hr}$ urinary phosphate in comparison to control group. On correlation analysis there is a strong positive correlation between the amount of daily fluid intake and $24 \mathrm{hr}$ urine output, weak negative correlation between $24 \mathrm{hr}$ urine calcium and magnesium, weak positive correlation between $24 \mathrm{hr}$ urine calcium and $24 \mathrm{hr}$ urine protein, and weak positive correlation between Serum Calcium and $24 \mathrm{hr}$ urine phosphorus. Study done by Jawlekar et al also revealed that levels of urinary magnesium and citrate were found to be lower than normal in patients with urolithiasis. ${ }^{3}$

\section{CONCLUSION}

Calcium oxalate is the most common type of stone in our perspective. None of our patients with urolithiasis had abnormal serum and urinary biochemical parameters. Abnormal serum or urine biochemical parameter alone is not the risk factor for urolithiasis. This different result may have arisen from the special characteristics of our patients (diet, climate, genetics, socio-economic factors, etc.). Not only this, the normal value of biochemical parameters for our population may need readjustment as we are following all western values which may not exactly fit in our context. There are correlations among some urine parameters in patients with urolithiasis and this may be clinically useful for a more effective treatment planning.

\section{REFERENCES}

1. Moe OW. Kidney stones: pathophysiology and medical management. Lancet 2006; 367:333-44.

2. Pak CYC, Resnick MI, Preminger GM. Ethnic and geographic diversity of stone disease. Urology 1997; 50:504-7.

3. S Jawalekar,VT Surve, AK Bhutey Twenty four hours urine and serum biochemical parameters in patients with urolithiasis Nepal Med Coll J 2010; 12(1): 5-7.

4. Borghi L, Meschi T, Amato F, Briganti A, Novarini A \& Giannini A (1996): Urinary volume, water and recurrences in idiopathic calcium nephrolithiasis: a 5-year randomized prospective study. J. Urol. 155, 839-43. 